\title{
'I am like a green olive tree': The Wisdom context of Psalm 52
}

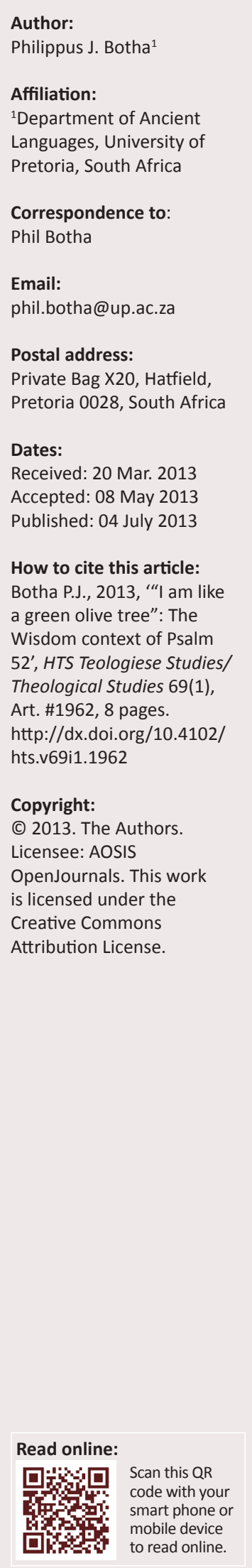

The article revisits the thesis of Walter Beyerlin from 1980 that Psalm 52 is a paraeneticdidactic Wisdom poem from the late Persian period. Beyerlin reached his conclusion from a comparison of Psalm 52 with post-exilic Wisdom psalms such as Psalms 37, 49, and 73. The direct literary influence that Psalm 52 received from the book of Proverbs and the motifs it shares with Jeremiah 9 are investigated here, since the author contends that the Wisdom influence on the Psalm was even greater than Beyerlin had envisaged. The article comes to the conclusion that the author(s) of the Psalm attempted to compose a psalm by establishing a network of allusions to a corpus of authoritative texts, inter alia, the Wisdom psalms. The end product is a brilliant composition which interprets the teaching of Proverbs for the needs of a group of Jewish believers who probably lived at the end of the Persian period.

\section{Introduction}

This article is an attempt to determine the literary context, and from this, the probable theologicalhistorical context for the understanding of Psalm 52. ${ }^{1}$ A similar investigation has been undertaken by Walter Beyerlin more than 30 years ago (Beyerlin 1980). Beyerlin came to the conclusion that Psalm 52 is a paraenetic-didactic Wisdom poem with the objective of leading the community in which it was composed out of its distress and crisis to a renewed hope of salvation and trust in Yahweh (Beyerlin 1980:92). The time of its composition was dated between the middle of the 5th century and the second half of the 4th century BCE (Beyerlin 1980:95).

Beyerlin based his investigation largely on the literary connections of Psalm 52 with Psalms 37, 49 , and 73, three important post-exilic Wisdom poems. He was unfortunately not taken seriously enough. A reconstructed cultic use of the Psalm is still seen by many as the proper key for interpreting the Psalm. ${ }^{2}$ In their recent, authoritative and thorough exposition of Psalm 52, Hossfeld and Zenger (2007:64-65) play down the connections Beyerlin found between Psalm 52 and postexilic Wisdom psalms. They state that they do not deny the Wisdom character of the Psalm, but would like to emphasise that that is only one characteristic of the 'Psalms of the Poor' (amongst others) and that the connections are not as strong as Beyerlin asserts (Hossfeld \& Zenger 2007:64). ${ }^{3}$

It is the objective of this article not only to confirm the findings of Beyerlin, but also to submit that even he has underestimated some important Wisdom connections and that the Psalm should most probably be interpreted as a late Persian period composition in which the author deliberately alluded to Proverbs in order to apply Wisdom teaching to the problems of his community. ${ }^{4}$ It could not, as Hossfeld and Zenger think, have originated in its present form in the time of the First Temple (Hossfeld \& Zenger 2007:65). The connections with especially Proverbs; Psalm 49, and Jeremiah 9 (in addition to its links with Pss 37 \& 73) seem to prove that Psalm 52 should be treated as a literary creation ${ }^{5}$ similar to Psalm $12^{6}$ which was intended to provide hope to victims of

1.In investigating its Wisdom connections, I intend also to pay tribute to James Alfred Loader in whose classes I had the privilege of sitting both as an undergraduate and a post-graduate student. He has made a tremendous impact on my training and, consequently, my career. The article is a joint venture with my colleague, Henk Potgieter, and this part of the investigation is based on his structura and poetic analysis of the Psalm, in his article 'The profile of the rich antagonist and the pious protagonist in Psalm 52' (Potgieter 2013).

2.Cf. for example, Broyles's attempt to interpret Psalm 52 as belonging to a regular liturgy which was probably used during a pilgrimage festival (Broyles 2005:275-280 \& 284-287). Seybold (1996:215) thinks of an asylum- or sanctification procedure in a temple tribunal and interprets the whole Psalm in terms of this process. Weber (2001:239) has a similar juridical process in mind in his explanation, but calls the Psalm an enemy-psalm ('Feindpsalm'). Weiser $(1955 \cdot 278)$ thinks of a process of the covenant community based on ritual law and points to the pre-exilic covenant community rather than the religious parties of late Judaism as the authors of the Psalm.

3.Van der Ploeg (1973:324) similarly speaks of expressions reminiscent of Wisdom literature, but denies that any direct citations or borrowing took place.

4.Beyerlin declares that the thematic substance of Psalm 52 can also be found in Proverbs. He recognises the similarities between Psalm 52 and Proverbs 11:28, for instance (Beyerlin 1980:23), but ascribes this to a general sapiental tradition instead of literary dependence (Beyerlin 1980:24-25).

5.Wilson (2002:785) provides one welcome exception to the rule of cultic interpretation of Psalm 52 by stating that the Psalm, although it is not explicitly instructive like Psalm 49, does offer instructive insights by its comparison of the two ways of righteousness and wickedness.

6.In this regard, see Botha (2012:40-56) 
TABLE 1: The structure and a translation of Psalm 52.

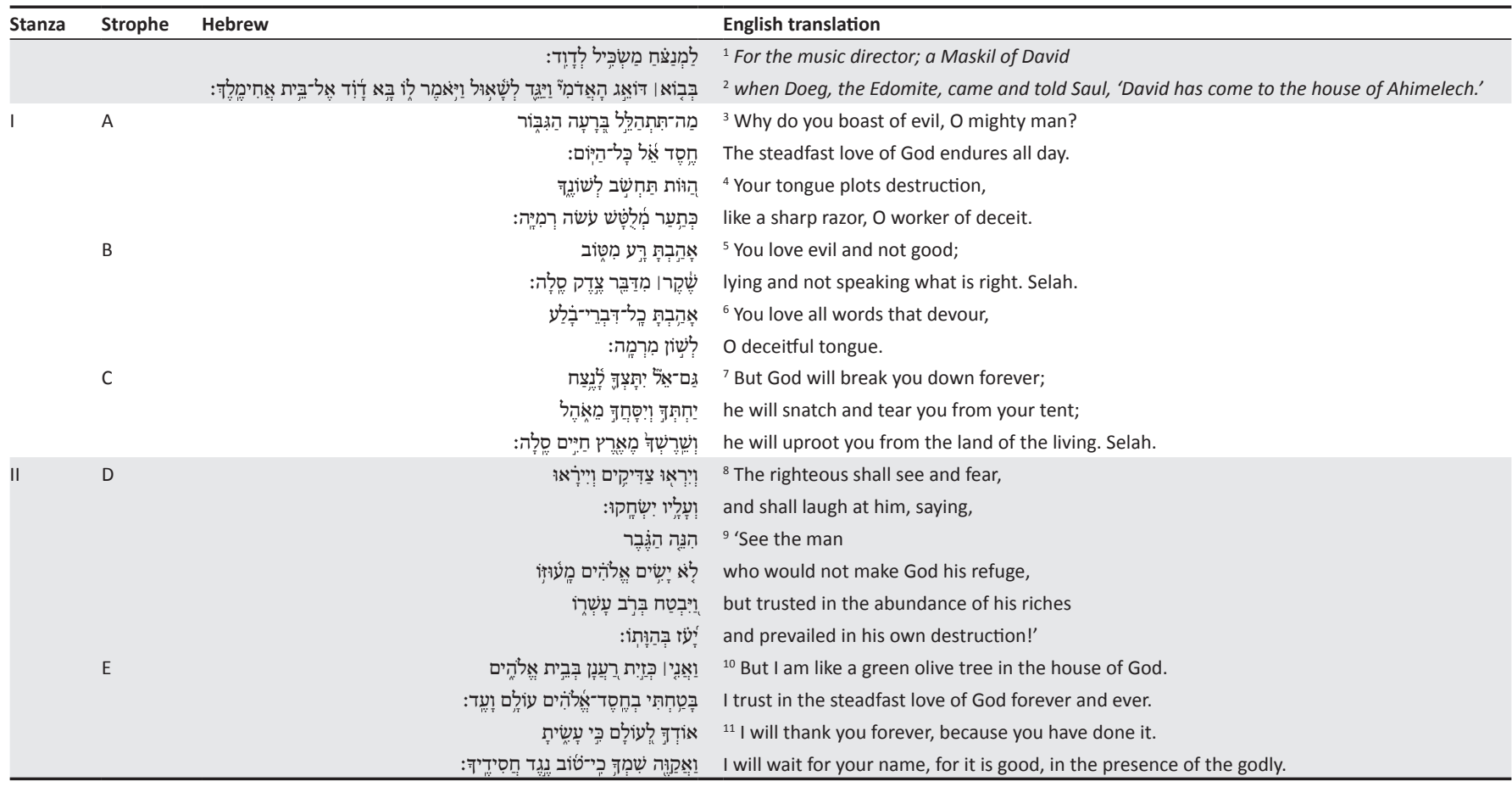

religious, social and financial exploitation in the late Persian period. ${ }^{7}$ The Sitz im Leben of the Psalm is rather an attempt to interpret what had by then been regarded as the authoritative teaching of Yahweh by a teacher of the Torah in a situation of exploitation, and certainly not a legalistic rite of the cultic community to sanction a curse on one of its members who was condemned to punishment by death for his misdeeds, as Weiser (1995:279) would have us believe.

Psalm 52 is not a haphazard compilation of pre-existent texts, but a cleverly devised instrument of communication which was subsequently provided with a heading to integrate it into a developing corpus of canonical texts. Its contents seem to be arranged to form two stanzas, the first of which has three strophes and the second two. The stichs and verse lines have been demarcated in accordance with the Masoretic system of accents rather than a hypothetical metrical scheme (see Table 1).

\section{Psalm 52 as an exposition and application of the teaching of Proverbs}

Hossfeld and Zenger are aware of the similarities between Psalm 52 and the 'Psalms of the Poor', Psalms 4 and 11-14. ${ }^{8}$ They seem to be unaware, however, of the extent to which these psalms were influenced by Proverbs and still describe them as 'vorexilische Armenpsalmen' (Hossfeld \& Zenger 2007:63). ${ }^{9}$

7.Reichenbach (2011:116) discusses the dating of Proverbs 1-9 and comes to the conclusion that it was composed in the late Persian period (450-333 BCE). He says it cannot be determined more precisely, but nevertheless suggests that the probable date of finalisation would be in the decades shortly before 333 BCE if Psalm 52 is social problems in Judah.

8.They provide a comparison of the similarities in form and content between Psalm 52 and these psalms. Cf. Hossfeld and Zenger (2007:62-63).

9.It will be argued that the author of Psalm 52 had the book of Proverbs at hand in more or less the same form that it has today and this could hardly have been in existence before the exile.
I have recently suggested that these psalms and Psalm 12 in particular constitute a response to and an explication of Proverbs 30:1-14 and that the connections with the prophetic books in these psalms are to be explained as a result of a similar influence exerted by Proverbs on the prophetic books (cf. Botha 2012:40-56). In making these assertions, I was merely following the lead provided by Bernard Gosse (2007:528-538) and working this out in greater detail in the case of Psalm 12. In the case of Psalm 52, it could therefore be prudent to attempt to prove the dependence of the Psalm on Proverbs and to investigate the connections between Proverbs, Psalm 52 and Jeremiah 9, since the last mentioned chapter also displays remarkable similarities with Psalm 52.

The implication, which will not be investigated further here, is that there is also a dependency of Jeremiah 9 on Proverbs, and a complex process of composition and editing of both Psalms and Jeremiah in which the book of Proverbs played a decisive role. In this regard, the whole thesis of Bernard Gosse seems to be vindicated. ${ }^{10}$ With regard to Psalm 52 specifically, Gosse has noted a connection with Proverbs 2:22 on the theme of the punishment of the wicked. He points out that the verb נסח [to tear away] which is used in Psalm 52:711 occurs only in this verse in the Psalter and elsewhere only in Deuteronomy 28:63, ${ }^{12}$ Proverbs 2:22 $2^{13}$ and Proverbs 15:25, ${ }^{14}$ proving a literary connection with Proverbs (Gosse 2007:76). The mention of the 'tent' in Psalm 52:7 from which

10.Cf. the introduction to his book (Gosse 2007:11-21).

11.'But God will break you down forever; he will snatch and tear you (ויסחך) from your tent; he will uproot you from the land of the living.'

12.'[A]nd you shall be torn out (ונסחתם) of the land that you are entering to take possession of it.'

13.'But the wicked will be cut off from the land, and the treacherous will be torn out (יסחו, to be read as a Hof'al) of it.'

14.'Yahweh will tear down (יסח) the house of the haughty people.' 
the 'mighty man' will be torn away and the assertion that the 'house' of the 'haughty persons' will be 'torn down' in Proverbs 15:25 further strengthens the connection with Proverbs. Deuteronomy 28:63 probably displays the same dependency on Proverbs 2:22.

Hossfeld and Zenger (2007:66-70) refer to the following verses which display thematic similarities between Psalm 52 and Proverbs or both Proverbs and Jeremiah:

- verse 3: Proverbs 16:32; 21:22; 24:5; 25:14; $27: 1$ and Jeremiah 9:22-23

- verse 4: Proverbs 11:6 and 18:21

- verse 5: Proverbs 6:12-19; 12:13-19; 14:6a and Jeremiah 9:2 and 4

- $\quad$ verse 7: Proverbs 2:22; $12: 3$ and 30:14

- $\quad$ verse 9: Jeremiah 17:7; Proverbs 10:2; 11:4, 28 and 18:23

- verse 10: Proverbs 11:28, 30; 15:4; 20:22; 23:27-28; 24:14 and Jeremiah 17:7-8.

They are thus aware of the sapiental and prophetic connections, and the importance of especially Proverbs 10-12 as well as Jeremiah 9 and 17 in the interpretation of Psalm 52 as is evident from this list compiled from their commentary. They would, however, describe these connections as similarities rather than allusions and did not undertake a systematic investigation. When the connections are compared more synoptically, it becomes clear that Psalm 52 does not only contain more connections with Proverbs than Hossfeld and Zenger as well as Gosse have pointed out, but that the Psalm presents the reader with a résumé and application of the teaching of Proverbs on the difference between righteous and wicked people in terms of trust, the misuse of power and speech, the judgement of Yahweh, and true blessedness.

It is perhaps important to point out that the use of rare words in two different contexts, especially if they are used in the same נסח expression or with similar subjects and objects (such as which was discussed above), can be used to prove a literary interconnectedness. A multitude of thematic correspondences should, however, not be disregarded. It seems that the author of Psalm 52 had internalised the teaching of Proverbs and then re-cast this teaching - which speaks in the third person about fools and wise people and wicked and righteous persons - in a direct, second person address to the wicked and to Yahweh. In doing this, he has not necessarily used the same words, but has often expressed exactly the same idea in different terms and in a simulated dialogic situation instead of a simulated didactic one.

What are the issues addressed in Psalm 52?:

- The presumptuous boasting ('Why do you boast?') of a wicked person ('of evil', 'O worker of deceit') who has attained a position of power ('O mighty man') through schemes of (verbal) deception ('your tongue plots destruction') is criticised.

- The audience is assured of the protection provided by the steadfast love of God for the righteous ('The steadfast love of God endures all day').
- The destructive and deceitful use of language ('your tongue plots destruction', 'O deceitful tongue', 'you love lying and not speaking what is right') which harms innocent people ('like a sharp razor', 'you love all words that devour') are criticised and unmasked as taking the wrong option when choosing between good and evil ('you love evil and not good, lying and not speaking what is right').

- The wicked are warned that God will punish them by using metaphors suggesting the demolishing of a house ('God will break you down forever') or the uprooting of a tree in a strong wind ('he will snatch and tear you from your tent', 'he will uproot you from the land of the living').

- The righteous are assured and the wicked are warned that public ridicule ('they shall laugh at him') and renewed respect for Yahweh ('the righteous shall see and fear') will result when God punishes the wicked ('because you have done it').

- The attitude of the wicked who disregard Yahweh as a place of refuge ('see the man who would not make God his refuge', 'and was strong in his own destruction') and who trust in their riches ('but trusted in the abundance of his riches') is criticised.

- The typical attitude of the righteous is commended, namely to trust in the steadfast love of God ('I trust in the steadfast love of God forever and ever'), to thank God always ('I will thank you forever'), and to wait for his name in the presence of the godly ('I will wait for your name, for it is good, in the presence of the godly'), since

- The righteous is assured of stability and blessing, comparable to the vitality of a green olive tree which was planted in the house of God ('but I am like a green olive tree in the house of God').

\section{Psalm 52 as an assertion of the teaching of Proverbs 1-3}

It would seem that the author of Psalm 52 had absorbed the teaching of Proverbs and echoed this teaching in a similar way as is the case in, for instance, Psalm 1 and Psalm 37. The connections between Psalm 52 and the post-exilic Wisdom Psalms which Beyerlin had studied turn out to be the result of a mutual indebtedness to Proverbs and inter-connectedness by way of common origin or editing. The links with Proverbs 1-3 mean that the book of Proverbs was probably available to the author of the Psalm in more or less the same form that it has today in the Masoretic tradition. The Psalm seems to echo the teaching of Proverbs 1-3 in the following ways:

- Proverbs 1:12 warns the student of Wisdom not to join in when invited by sinners to ambush innocent people in order to swallow (בלע) them alive. In Psalm 52:6, the antagonist is accused of loving 'all words that devour' (בלע). Through this allusion, the antagonist in the Psalm is described by implication as a 'sinner' (Pr 1:10) who is

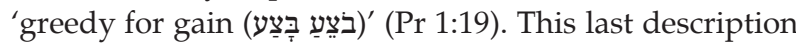
is congruent with the representation in the rest of the Psalm, since the antagonist is described, using a different expression, as someone who 'seeks refuge in his own

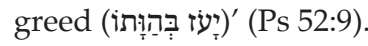


- In Proverbs 1:16, the feet of the sinners against whom the student of Wisdom is warned, are said to 'run' to evil (רע). The antagonist of Psalm 52:5 in turn is said to 'love' evil (רע) and not good. He therefore has the same inclination.

- The 'simple ones' of Proverbs 1:22 are asked how long they will love (אהב) simplicity. The antagonist of Psalm 52 is accused of loving (אהב) evil and not what is good (v. 5), lying and not speaking what is right (v. 5) and also of loving (אהב) - all words that devour (v. 6). Through multiple allusions to Proverbs 1-3 (see below), the author of Psalm 52 has thus amalgamated the description of the 'sinners' in Proverbs 1:7-19 with that of the 'simple', the 'scoffers', as well as the 'fools' found in Proverbs 1:22-33. The author of Psalm 1 has also fused the two types (cf. the clever combination of 'sinners', חטאים, from Proverbs 1:10, the 'road' metaphor from Proverbs 1:15 and the 'scoffers', לצים, from Proverbs 1:22 in Psalm 1:1).

- In Proverbs 1:26, Lady Wisdom warns that she will laugh (שחק) when calamity strikes the fools who would not listen. ${ }^{15}$ The antagonist of Psalm 52 is warned in a similar way that the righteous will laugh (שחק) when God breaks him down and tears him from his tent (v. 8).

- According to Proverbs 1:27, terror will strike the fools like a storm and calamity come on them like a whirlwind; those who listen to Lady Wisdom, on the other hand, will dwell securely (Pr 1:33). The punishment of the antagonist is described in Psalm 52:7 as the demolishing of a house and the uprooting of a tree similar to what takes place in a storm; the protagonist, in contrast to this, is confident that he is safe like a green olive tree in the house of God (Ps 52:10), calling to mind also the image of Psalm 1:3 and 4.

- Proverbs 2:12 and 14 promise that Wisdom will rescue the student of Wisdom from the way of evil (רע)), from people who speak (מדבר) deceitfully (תהככות) and who rejoice in doing evil (עשה רער (מער). The antagonist of Psalm 52 is accused of loving evil (רע) and lying and not speaking (דבר) what is right, whilst he is also called a worker of deceit (עשה רמיה).

- Proverbs 2:22 warns that wicked people will be cut off from the land (ארץ) and treacherous people will be torn out (נסח) of it. According to Psalm 52:7, the antagonist will be snatched and torn (נסח) from his tent and uprooted from the land (ארץ) of the living. He is consequently identified with the 'wicked' and 'treacherous' people of Proverbs 2. The threat is no longer expropriation, however, but death. This is in line with the teaching of Psalm 49:12-15 which is also reflected in Psalm 52.

- Proverbs 3:5 admonishes the student of Wisdom to trust (בטח) in Yahweh with his whole heart; the speaker of Psalm 52:10 confesses that he trusts (בטח) in the steadfast love of God forever and ever. The formulation is less direct, and the speaker in Psalm 52 also declares that he will wait for the name of God, rather than for God as is advised in Proverbs 20:22. ${ }^{16}$ This could be taken to suggest a gap in time between the publication of Proverbs and the composition of Psalm 52.

15.The editor of Psalm 2 has combined the verbs לעי from Proverbs $1: 16$ in Psalm 2:4, with Yahweh in the role of Lady Wisdom. The Proverbs image has also inspired Psalm 37:13 (the Lord laughing - שחק - at the wicked), a Psalm which is a close relative of Psalm 52. Cf. in this regard the work of Beyerlin (1980:46-47).

16.'Do not say, “I will repay evil!" Wait (קוה) for Yahweh, and he will deliver you.'
- Proverbs 3:7 admonishes the student of Wisdom not to be wise in his own eyes, but to fear (ירא) Yahweh and turn away from evil (רע); the antagonist of Psalm 52 is accused of boasting in evil (רעה) and loving it (רער) and not good (vv. 3, 5); the reaction of the righteous when he is punished, on other hand, is that they will fear (ירא, v. 8). The antagonist of Psalm 52 is consequently described by implication as the opposite of a wise person, since he is arrogantly pursuing evil, whilst the teaching of Proverbs is vindicated when his punishment comes and the righteous people respond with greater reverence for God.

- Proverbs 1-3 uses tree imagery to warn the fools that they will eat the fruit of their actions (Pr 1:31) and to propagate Wisdom as a tree of life for all who embrace it (Pr 3:18). At the same time, it warns that wicked people will be 'torn from' the land (Pr 2:22). Psalm 52 uses tree imagery to warn that the wicked person will be uprooted from the land of the living (v. 7) and to describe the verdancy of the righteous person who trusts in God's steadfast love (v. 10). ${ }^{17}$ This provides another parallel with Psalm 1 where verdancy and fruitfulness are contrasted with the instability of chaff in a wind.

\section{Psalm 52 as a reflection of the teaching of Proverbs in general}

Many of the themes found in the first three chapters of Proverbs are treated more extensively in the rest of Proverbs, whilst the rest of Proverbs also provides more detailed parallels to Psalm 52.

\section{Pride goes before destruction}

The Psalm, for instance, reflects the general Wisdom teaching that arrogance is especially hateful to Yahweh, that arrogance comes to a fall and that self-trust and self-reliance lead to eventual shame and disgrace. ${ }^{18}$ This theme is encountered in Proverbs 8:13, for instance, which teaches that the fear of Yahweh implies to hate (שנא) evil (רעא) and that Lady Wisdom hates (שנא) pride, arrogance, the path of evil (דרד רע), and the perverse mouth. This verse features ironically in Psalm 52, since the seemingly 'mighty man' of Psalm 52:3 is ridiculed for boasting (תתהלל) in evil (רע) and is said to love (אהב) evil (רע) (בטח) (20) in the abundance of his riches (עשרו ברב, 52:9). By loving what she hates, he is thus the opposite of Lady Wisdom and a prime example of someone who does not fear Yahweh.

On the matter of trust, the Psalm also seems to allude directly to Proverbs 11:28, where the warning is issued that 'he who trusts in his riches (בוטח בעשרו) will fall, but the righteous (צדיקים)

17.Cf. the same motif also in Proverbs 11:28.

18.In this regard, Psalm 52 is a close companion of Psalm 12 which was probably written in similar or the same circumstances. Cf. Psalm 12:4-5: 'May Yahweh cut off all flattering lips, the tongue that speaks great things (גדלות), that says, "With our tongue we will prevail (נגביר), our lips are with us; who is master over us?"' It is a characteristic of the prayers formulated by the post-exilic Wisdom editors of the Hebrew Bible that they, who probably referred to themselves as the חסידים, singled out the arrogance of their opponents and their own humility as the most importan marks of distinction between the two groups. Cf. the contrast in the Song of Hannah in 1 Samuel 2:9 (The feet of his faithful ones [חסידיו] he will guard, but the wicked will be cut off in darkness, for a man shall not prevail [יגבר] through power'). Cf. also the contrast between the חסיד and the רמים 2 Samuel 22:26-28. 
will flourish like foliage.' This verse in Proverbs helps us to understand why the antagonist's downfall in Psalm 52 is described as being 'uprooted' (שרשש) from the land of the living, and why the protagonist's confidence is compared to 'a green olive tree in the house of God' (Pss 52:7 \& 10). Proverbs 12:3 also seems to have played a role: 'A man shall not be established by wickedness; but the root (שרש) of the righteous (צדיקים) shall not be moved.'

Proverbs teaches in a number of places that Yahweh hates haughtiness ${ }^{19}$ and it uses the same word (תתהלל) as Psalm 52:3 to discourage boasting about the day of tomorrow $(\operatorname{Pr} 6: 17)$. It is difficult to avoid the deduction that this verse, together with Proverbs 11:28 and others, served as an inspiration for Psalm 52:3. Similarly, in Proverbs 30:8-9, the author asks to be given neither poverty nor riches (אשר) in order to prevent him from shaming the name of Yahweh and becoming arrogant and consequently denying dependence on Yahweh. According to Proverbs, the problem with being rich is precisely that wealth might seem to provide protection. According to Proverbs 10:15, a rich man's wealth is his fortified city (קרית עזו) whilst according to Proverbs 13:8, the ransom for the life of some people is their riches (עשרו). Psalm 49:8 corrects the wrong understanding of this verse in Proverbs by stating explicitly that no one can give a ransom for someone else's life, and Psalm 52 links up with both Proverbs 13:8 and Psalms 49:7 and 8. The criticism of Psalm 52:9 is levelled precisely at the antagonist who would not make God his refuge (מעוזו), but trusts in the abundance of his riches (cf. also Ps 49:7) and seeks refuge in his own greed (יעז בהותו). Such desire (הוה) can become a trap which captures the faithless, according to Proverbs 11:6.

\section{Judgement in the form of a whirlwind}

It has already been pointed out that the author of Psalm 52 uses tree imagery to describe the divergent fates of the evil antagonist and faithful protagonist. Within this allegorical complex, calamity in the form of a storm will put an end to the prosperity of the wicked according to Proverbs. The same motif is also found in Psalm 1 and Psalm 52 and there is little doubt that it has been extracted from Wisdom. Proverbs 2:22 namely promises that the treacherous will be torn out (נסח) of the land. Proverbs 10:25 defines the calamity more clearly: 'When the whirlwind passes, the wicked is no more, but the righteous is established forever.' Proverbs 12:3 adds to this: 'No one can be established (כון) through wickedness, but a righteous root (שרשש) cannot be moved.' It thus seems significant that Psalm 52:7 uses the cognate verb of the noun

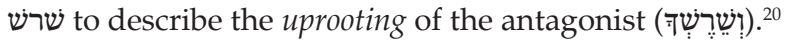

But the author of Psalm 52 also refers to the house imagery of Proverbs in a very clever way. He contrasts the fate of the antagonist, who will be 'torn' from his 'tent' with that of the

19.Cf. Proverbs 6:17 and 30:13.

20.It is possible that Jeremiah $11: 19 \mathrm{~b}$ also contributed to the formulation of this verse: 'Let us destroy the tree with its fruit, let us cut him off from the land of the living (מארץ חיים), that his name be remembered no more.' Cf. also the occurrence of the expression 'a green olive tree' in Jeremiah 11:16 and the same image in Psalm 52:10. Jeremiah 11:16 uses the image of a storm combined with fire to define the consuming power of Yahweh's judgement. protagonist, who is like a green olive tree in the 'house' of God (vv. $7 \& 10$ ). The use of the word 'tent' already implies a lack of permanency, whilst the 'house of God' and the suppliant's trust in the steadfast love of God 'forever and ever' stand in stark contrast to this lack of permanency. A similar discrepancy is therefore offered as the one found in Proverbs 3:33 where it says, 'the curse of Yahweh is in the house (בית) of the wicked; but he blesses the home (נֶָָ) of the righteous.' The positive association of 'house' and the negative association of 'tent' are inverted in Proverbs 14:11 which basically have the same teaching: 'The house of the wicked shall be overthrown; but the tent of the upright shall flourish.' This reversal can possibly be explained as an emphasis on the greater prosperity of the wicked or an idealisation of the trust of the Israelites who relied on Yahweh when they lived in tents in the wilderness. However it may be that the author of Psalm 52 made a clever choice by strengthening the antithesis through association of 'tent' with the antagonist and contrasting this with the 'house' of God, not of an individual righteous person. The same motif of demolition and uprooting by trial through storm is also found in Proverbs 10:25 where it says: 'When the storm passes through, the wicked is no more, but the righteous is established forever' and Proverbs 10:30 which states that: 'The righteous will never be removed, but the wicked will not dwell in the land.' Proverbs 12:7 similarly declares that: 'The wicked are overthrown and are no more, but the house of the righteous shall stand.' The author of Psalm 52 has therefore made effective and innovative use of a metaphorical complex about the fate of the wicked and that of the righteous which is well documented in Proverbs.

\section{Yahweh abhors evil schemes}

Another theme which was already encountered above in Proverbs 1:10-14 is that of the plotting and planning of wicked people to do harm to innocent people. It is found very often in Proverbs, and is also reflected in Psalm 52. The student of Wisdom is for example warned in Proverbs 3:29, 'do not plot (אל־תחרש) evil (רעה) against your neighbour.' In Proverbs $6: 14$, worthless and unjust people are described as those 'in whose heart is perversion' and who are 'plotting (ברשל (ברש)) evil (רע) continually (בכל־עת).'21 Proverbs 15:26 in turn warns that 'Yahweh abhors the plans of the wicked (מחשבות רע)' and Proverbs 24:2 says evil men's 'hearts contemplate (מחרע) violence (שד) and their lips speak harm.' In Psalm 52, the antagonist is also accused of evil planning, especially of verbalising these evil schemes with a dangerous tongue. Through metonymy, the 'tongue' of the antagonist is said in verse 4 to 'plot destruction (הוות תחשב).' The antagonist is described in the same verse as a 'worker of deceit' who uses his tongue like a sharp razor, that is, as a weapon against other people. Similar metaphors are found in a number of places in Proverbs. Proverbs 11:9 says that the godless person uses his mouth to destroy his neighbour. According to Proverbs 12:18, the 'rash words' of some people are like sword thrusts, whilst the tongue of the wise heals. In the same vein, Proverbs 30:14 speaks of those 'whose teeth are swords, whose molars

21.In this regard, it may be meaningful that Psalm $52: 3$ asserts that 'the steadfast love of God [endures] all day' in the verse immediately preceding the accusation that the tongue of the 'mighty man' plots destruction. 
are knives to devour (לאכל) the poor from the earth and the needy from amongst the human race. ${ }^{22}$ This is reminiscent of the connection I have pointed out above between the 'words that devour (בלע)' in Psalm 52:6 and the people who plan to 'swallow'(בלע) innocent people alive in Proverbs 1:12.

\section{Wrongful use of language}

One last similarity between Psalm 52 and Proverbs that should be discussed is the motif of the misuse of language to deceive and take advantage of people. ${ }^{23}$ In addition to arrogant boasting in evil, the antagonist of Psalm 52 is accused of using his tongue to plot destruction (חשב הוה) (v. 4); using it like a razor for deception (רמיה) (v. 4); using it to lie (רבד שקר) instead of speaking what is right or just (צדק) (v. 5); and using it to form words that devour other people through deception of the tongue (לשון מרמה) (v. 6). Proverbs 13:5 teaches that a righteous person hates lying (דבר־שקר ישנא צדיק). Antagonist of Psalm 52 does the opposite, since he 'loves' lying (אהבת שקר) and avoids speaking what is right (דבר צדק). In view of the contrast, this is tantamount to saying that the antagonist of the Psalm is not a righteous person, but someone who is wicked (cf. Pr 13:5b). Deception, lying, the use of the mouth to commit violence and the tongue for destruction are often mentioned in Proverbs as the habit of fools and wicked people: Proverbs 14:8, 'the folly of fools is deception (מרמה)'; $10: 6 b(=10: 11 b)$ 'the mouth of the wicked conceals violence'; $10: 32$ 'the speech of the wicked is perverse'; 12:6 'the words of the wicked lie in wait for blood'; 12:17 'who speaks the truth (יפיח אמונה) gives honest evidence, but a false witness utters deceit (מרמה)'; 17:4 'a liar (שקר) pays attention to a destructive tongue (לשון־הות)'; 17:20 'he who is deceitful (נהפרן) with his tongue (בלשונו), falls into calamity.' The author of Proverbs 30:5-14 prays in verse 8, 'keep deception and lies far from me.' This last mentioned composition in Proverbs in fact lists a whole range of wrong uses of language - adding anything to the words of God and thus being found out as a liar (Pr 30:6); falsehood and lying (Pr 30:8); arrogant denial of God (Pr 30:9); slander and cursing (Pr 30:10); cursing and not blessing one's parents (Pr 30:11); and using one's mouth to devour the poor and the needy (Pr 30:14). It would seem that the author of Psalm 52 drew strength from the unanimous condemnation of presumed influential people in Proverbs and propagated its message of hope to those righteous and pious people who suffered as a result of such arrogance and verbal exploitation. In this regard, Psalm 52 seems to be a close relative of Psalm 12.

\section{The relationship of Psalm 52 with Jeremiah 9}

When all the places where the expression 'to boast in' (התהלל ב) occurs in the Hebrew Bible are compared, it immediately becomes clear that there must be a close relationship between Jeremiah 9:22-23 and Psalm 52:3. The Jeremiah text appears to

22.Cf. the occurrence of similar images in Psalms $53: 5,57: 5,59: 8,64: 4$ and $140: 4$; and see Proverbs 25:18: 'A man who bears false witness against his neighbour is a war club, and a sword, and a sharpened arrow.'

23.This is considered to be a serious transgression in the Old Testament, according to Van der Ploeg (1973:326), who also refers to Psalm 59:8 in addition to Proverbs 17:4 and $12: 18$ be the donor text in this case. Especially Jeremiah 9:22bc, 'and let the mighty man not boast in his might, let the rich man not boast in his wealth' (ואל-יתהלל הגבור בגבורתו אל-יתהלל עשיר בעשרו) seems close to Psalm 52:3, 'why do you boast in evil, O mighty man?' (מה־תתהלל ברעה הגבור). The connection is further strengthened by the description of the 'mighty man' in Psalm 52:9 as someone who 'trusted in the abundance of his riches' (ויבטח ברב עשרו), since riches are mentioned in Jeremiah 9:22c as that about which the rich man boasts. The antagonist of Psalm 52 is thus both powerful and rich. The matter is further complicated when we consider that Proverbs 11:28 was identified above as one of the sources used by the author of Psalm 52:9 ('He who trusts in his wealth will fall, but the righteous will flourish as foliage'), and Psalm 49:7 is also drawn into the comparison ('those who trust in their wealth and boast in the abundance of their riches') ${ }^{24}$ It definitely seems as if the author of Psalm 52 had access to Proverbs 11:28, especially if verses $27-31$ as a whole are taken into account:

The one who diligently seeks good (טוב) seeks favour, but the one who searches for evil (בע) - it will come to him. [25] The one who trusts in his riches (בוטח בעשרו) will fall, but the righteous (צדיקים) will flourish like a green leaf. The one who troubles his family will inherit nothing, and the fool will be a servant to the wise person. The fruit of the righteous (צדיק) is a tree of life (חיים), and the one who saves lives $\left.{ }^{[2]}\right]$ is wise. If the righteous are recompensed on earth (ארץ), how much more the wicked and the sinner!

Jeremiah 9:22 is critical for three types of boasting: wise people 'boasting in their wisdom'; a mighty man (הגבור) 'boasting in his might'; and a rich person 'boasting in his riches' (עשיר בעשרו יתהלל). In the next verse, the instruction is given that anyone who would want to boast should boast about the fact that they understand and know Yahweh and know that he practices steadfast love (חסד), justice, and righteousness on earth (or: in the land), the things in which he delights. It would seem that the author of Psalm 52 combined two of the three parallel types of boasting found in Jeremiah 9:22 the person who considers himself to be a 'mighty man' is now said to boast in 'evil'; but he is the same person who 'trusted (instead of 'boasted') in the abundance of his riches.' Jeremiah 9:22 could thus have been combined with Proverbs 11:28 to arrive at the portrayal of a wicked man who boasts of evil and trusts in his abundant wealth. The notion of the abundance of riches the author of Psalm 52 probably borrowed from Psalm 49:7, since this addition to the Jeremiah text was necessary in Psalm 49:7 to form a chiastic parallel between 'who trust in their wealth and in the abundance of their riches they boast.' In this verse the psalmist of Psalm 49, who is busy encouraging himself not to be afraid of wicked deceivers, describes his opponents as people who 'trust their wealth' (הבטחים על־חילם) and 'boast in the abundance of their riches' (וברב עשרם יתהלים)), using in the second stich the same expression as in Jeremiah

24. Gosse $(2007: 160)$ identifies Proverbs $18: 11 ; 3: 7 ; 26: 12$; and $16: 8$ as well as Psalm $89: 3$ as sources for the composition of Jeremiah 9:22-23.

25.Psalm 34:15 similarly seems to have been inspired by Proverbs 11:27 - 'Turn away from evil and do good; seek peace and pursue it.' Anderson (1985:404) sees a connection between Psalm 52:5 and Psalm 34:15.

26.The second half of the verse has been translated as a parallel to the first half, taking it to mean that the righteous have a life-giving influence on those in their vicinity, saving the lives of other people through their prudence. See also the rendering of the New International Version (NIV) of this verse. 
BOX 1: Comparisons between Proverbs 11:28, Jeremiah 9:22-23, Psalm 49:7 and Psalm 52:3, 9.

\begin{tabular}{|c|c|}
\hline Proverbs 11:28 & 'He who trusts in his riches (בוטח בעשרו), will fall, but the righteous will flourish as foliage.' \\
\hline Jeremiah 9:22-23 & 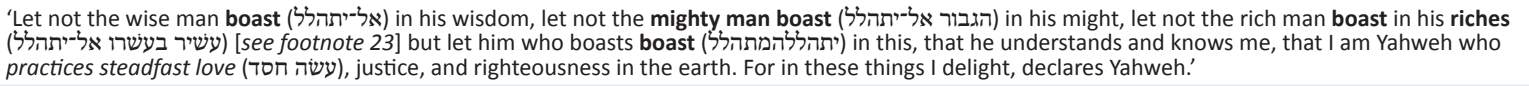 \\
\hline Psalm 49:7 & 'Those who trust in their wealth and boast in the abundance of their riches (עשרם יתהלל הבטחים על־חילם וברב)?' \\
\hline Psalm 52:3, 9 & 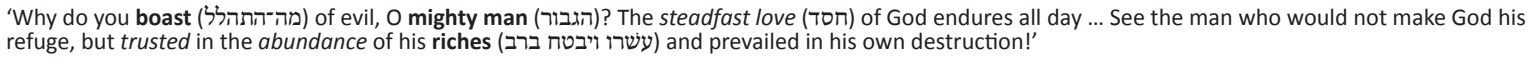 \\
\hline
\end{tabular}

9:22 (אל-יתהלל עשיר בעשרו), but in the plural. The verse in our Psalm seems to take cognisance of both Jeremiah 9:22 and Psalm 49:7, since it asks the 'mighty man' (הגבור, cf. its occurrence in Jeremiah 9:22) why he boasts 'in evil'. The connection with Jeremiah 9:22 and with Psalm 49:7 is found in the fact that the opponent is described later in the Psalm in Psalm 52:9 - as 'the man (הגבר) who would not seek refuge in God, but trusted in the abundance of his riches (ויברח ברב עשרו) and prevailed in his own destruction (יעז בהותו)'.

The four contexts can be compared as seen in Box 1 .

Psalm 49 focuses on the contrast between rich and poor people and the conviction of the rich people that their riches will save them. ${ }^{28}$ It then proceeds to explain that money is not able to redeem the soul of a person; that people who enjoy honour because of their riches will die like animals. The suppliant, however, is confident that God will redeem his soul from death and thus vindicate his trust in Yahweh. The author of Psalm 52 has taken over the motif of boasting in the abundance of one's riches from Psalm 49, but it seems that Jeremiah 9 also played a role in the composition of Psalm 52 , since the wicked is addressed as: 'O mighty man' and the combination of this epithet with the expression of 'boasting in' points to Jeremiah 9:22 as another context that was consulted. It is also possible that the parenthetic and cryptic note in Psalm 52:3b, '[ $t]$ he steadfast love of God endures all

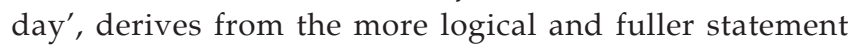
in Jeremiah 9:23 (MT) that proper 'boasting' is about the character of Yahweh as one who practices steadfast love, justice and righteousness on earth. This surmise is confirmed when Jeremiah 9:2-7 is inspected:

2. They bend their tongue (לשון) like a bow; falsehood (שקר) and not truth has grown strong (גבר) in the land; for they proceed from evil to evil (מרעה אל־רעה), and they do not know me, declares Yahweh. 3. Let everyone beware of his neighbour, and put no trust (בטחה) in any brother, for every brother is a deceiver, and every neighbour goes about as a slanderer. 4. Everyone deceives his neighbour, and no one speaks (דבר) the truth; they have taught their tongue (לשון) to speak lies (שקר); they weary themselves committing iniquity. 5. You live within deceit (מרמר), in deceit (מרמה) they refuse to know me, declares Yahweh. 6. Therefore thus says Yahweh of hosts: 'Behold, I will refine them and test them, for what else can I do, because of the daughter of my people? 7. Their tongue (לשון) is a deadly arrow; it speaks deceitfully (מרמה דבר); with his mouth each

27.The noun plays an important role in the Psalm and other psalms in the vicinity: It occurs in Psalm 52:4 and 9; and also in Psalms 55:12 and 57:2. In all three psalms the destruction is associated with dangerous words and speech - cf. Psalm 55:10 and 22 (softer than butter and more soothing than oil, yet hiding war and really being drawn (softer than butter and more soothing than oil, yet hiding war and really being drawn tongue is a sharp sword). In these formulations, Proverbs 25:18 definitely seems to have been consulted.

28.Psalm 49:6-14 seems to be a polemic against a wrong interpretation of Proverbs 13:8. speaks (דבר) peace to his neighbour, but in his heart he plans an ambush (ישר (ישר ארבו) for him.'

The words that are in italics in this quotation are those that also occur in Psalm 52. It should be noted that Jeremiah 9:2-7 is generally considered to be an integral part of the surrounding text of Jeremiah - it seems to be part of a lament on the general social situation in Jerusalem before the fall of the city. Jeremiah 9:22-23, in contrast, does not seem to fit into its current context. It seems to interrupt the lament and can be described as 'a beautiful logion on true wisdom which is in the best tradition of wisdom literature' (Thompson 1980:318). It has also been described as an independent oracle placed here by an editor of Jeremiah, although it seems to reflect Jeremiah's thought expressed also in other places, that the social elite had forgotten Yahweh (Thompson 1980:318). There are thus a number of links between Psalm 52 and Jeremiah 9: The expression to 'boast in' something (הלל ב hitp; Ps 52:3 \& Jr 9:22-23); the fact that it is a 'mighty man' (גבור, Ps 52:3 \& Jr 9:22) who does the boasting; the mention of evil (רעה, Ps 52:3 \& Jr 9:2), and the motif of false speech, lying, and deceit (לשון, Ps 52:4, 5 \& Jr 9:2, 4, 7; שקר, Ps 52:5 \& Jr 9:2, 4; \& מרמה, Ps $52: 6 \& \mathrm{Jr} 9: 5,7)$. To this can be added the image of the tongue as a weapon - either a bow, used to shoot arrows (Jr 9:3), or an arrow itself which is intended to kill (Jr 9:8). In Psalm 52:4 the tongue is compared to a sharpened razor which itself plans destruction. The fact that Psalm 52, which is a coherent composition, displays connections to both parts of Jeremiah 9, suggests that Jeremiah 9 already existed as a literary text when Psalm 52 was composed. Psalm 52 thus constitutes an explication and application of three different 'canonical' contexts to the problems of a certain situation.

\section{Conclusion}

What has transpired from the investigation is that the author of Psalm 52 has composed a brilliant piece of teaching. It becomes a truly admirable piece of work when one realises that he created the composition by establishing connections to Proverbs, other Wisdom Psalms, and even Jeremiah in such a way that those texts are explained and applied to a certain problem of social imbalance and injustice. ${ }^{29}$ The same procedure of creating an authoritative text by quoting from and alluding to material that must have been available as part of an authoritative corpus of texts that one can see in the composition of Psalms 1, 3, 12, 19, 24, 31, 33, 34, 37, 91,

29.This characteristic of Wisdom psalms often led in older commentaries to certain phrases being ascribed to 'glossators'. Cf. for example, the last two words of verse 4 (עשה רמיה) being ascribed to a glossator who added it from Psalm 101:7 by Briggs and Briggs ([1907] 1925:13). Numerous other words in the Psalm are treated similarly, f. Briggs and Briggs ([1907] 1925:15-16). Weber (2001:239) thinks it possible that the contrast of 'good' and 'evil' in verses 5 and 11 could allude to Genesis 1:31; 2:17; 3:5 and 3:22. Cf. the way in which Psalm 33 alludes to and applies Genesis 1:2, 2:1 as well as Exodus 15:8. It is discussed in Botha and Potgieter (2010). 
119 and many others, ${ }^{30}$ was also used in the composition of Psalm 52. For the author of Psalm, Proverbs was immensely important, although his theological position had already shifted some distance from the teaching that one finds in Proverbs. The situation for which it was crafted must have been in the time which Beyerlin proposed, namely between 450 BCE and 300 BCE, a time when a number of Judeans experienced financial and political oppression by influential leaders from their own people.

\section{Acknowledgement Competing interest}

The author declares that he has no financial or personal relationship(s) which may have inappropriately influenced him in writing this article.

\section{References}

Anderson, A.A., 1985, The Book of Psalms: Psalms 1-72, vol. 1, Wm. B. Eerdmans, Grand Rapids.

Beyerlin, W., 1980, Der 52. Psalm, Studien zu seiner Einordnung, W. Kohlhammer Stuttgart/Berlin/Köln/Mainz.

30.Gosse (2007:15) points out how the author of Psalm 49 actually expresses his intention of reflecting from the perspective of Wisdom on the life of the psalmist in verses
$4-5$ and establishing a link with Proverbs 1:6 in doing this. For a fuller treatment of this, see also Gosse (2006:552-569).
Botha, P.J., 2012, 'Pride and the suffering of the poor in the Persian period: Psalm 12 in its post-exilic context,' Old Testament Essays 25(1), 40-56.

Botha P.J. \& Potgieter, J.H., 2010, "“The word of Yahweh is right": Psalm 33 as a TorahPsalm,' Verbum et Ecclesia 31, Art. \#431, 1-8. http://dx.doi.org/10.4102/ve.v31i1.431

Briggs, C.A. \& Briggs, E.G., [1907] 1925, A critical and exegetical commentary on the book of Psalms, vol. 2, T. \& T. Clark, Edinburgh.

Broyles, C.C., 2005, 'Psalms concerning the liturgies of Temple Entry,' in P.W. Flint \& P.D. Miller (eds.), The Book of Psalms, Composition and Reception, pp. 248-287, Brill, Leiden/Boston.

Gosse, B., 2006, 'Appel de la sagesse de Proverbes 1 et la constitution finale du Psautier', Revue Biblique 113(4), 552-569.

Gosse, B., 2007, 'L'influence de Proverbes 30:1-14 sur les cantiques bibliques, à travers le Psautier,' Zeitschrift für die Alttestamentliche Wissenschaft 119, 528-538. http:// dx.doi.org/10.1515/ZAW.2007.037

Gosse, B., 2008, L'influence du livre des Proverbes sur les rédactions bibliques à l'époque perse, Gabalda, Paris.

Hossfeld, F-L. \& Zenger, E., 2007, Psalmen 51-100, Herder, Freiburg/Basel/Vienna.

Potgieter, H.J., 2013, 'The profile of the rich antagonist and the pious protagonist in Psalm 52', HTS Teologiese Studies/Theological Studies 69(1), Art. \#1963, 7 pages. http://dx.doi.org/10.4102/hts.v69i1.1963

Reichenbach, G., 2011, Gültige Verbindungen, eine Untersuchung zur kanonischen Bedeutung der innerbiblischen Traditionsbezüge in Sprüche 1 bis 9, Evangelische Verlagsanstalt, Leipzig.

Seybold, K., 1996, Die Psalmen, J.C.B. Mohr, Tübingen. PMCid:1909888

Tate, M.E., 1990, Psalms 51-100, Word Books, Dallas.

Thompson, J.A., 1980, The Book of Jeremiah, William B. Eerdmans, Grand Rapids. Van der Ploeg, J.P.M., 1973, Psalmen deel I, Psalm 1 T/M 75, J.J. Romen \& Zonen, Roermond. Weber, B., 2001, Werkbuch Psalmen I, Die Psalmen 1 bis 72, Kohlhammer, Stuttgart. Weiser, A., 1955, Die Psalmen, Erster Teil: Psalm 1-60, 4. Aufl. Vandenhoeck \& Ruprecht, Göttingen.

Wilson, G.H., 2002, Psalms, vol. 1, Zondervan, Grand Rapids. 